This item was submitted to Loughborough's Research Repository by the author.

Items in Figshare are protected by copyright, with all rights reserved, unless otherwise indicated.

\title{
A consideration of reflexive practice within the critical projects movement
}

PLEASE CITE THE PUBLISHED VERSION

http://dx.doi.org/10.1016/j.jproman.2009.10.002

PUBLISHER

(c) Elsevier

VERSION

AM (Accepted Manuscript)

LICENCE

CC BY-NC-ND 4.0

REPOSITORY RECORD

Sage, Daniel J., Andrew R.J. Dainty, and Naomi Brookes. 2019. "A Consideration of Reflexive Practice Within the Critical Projects Movement”. figshare. https://hdl.handle.net/2134/11115. 
This item was submitted to Loughborough's Institutional Repository (https://dspace.lboro.ac.uk/) by the author and is made available under the following Creative Commons Licence conditions.

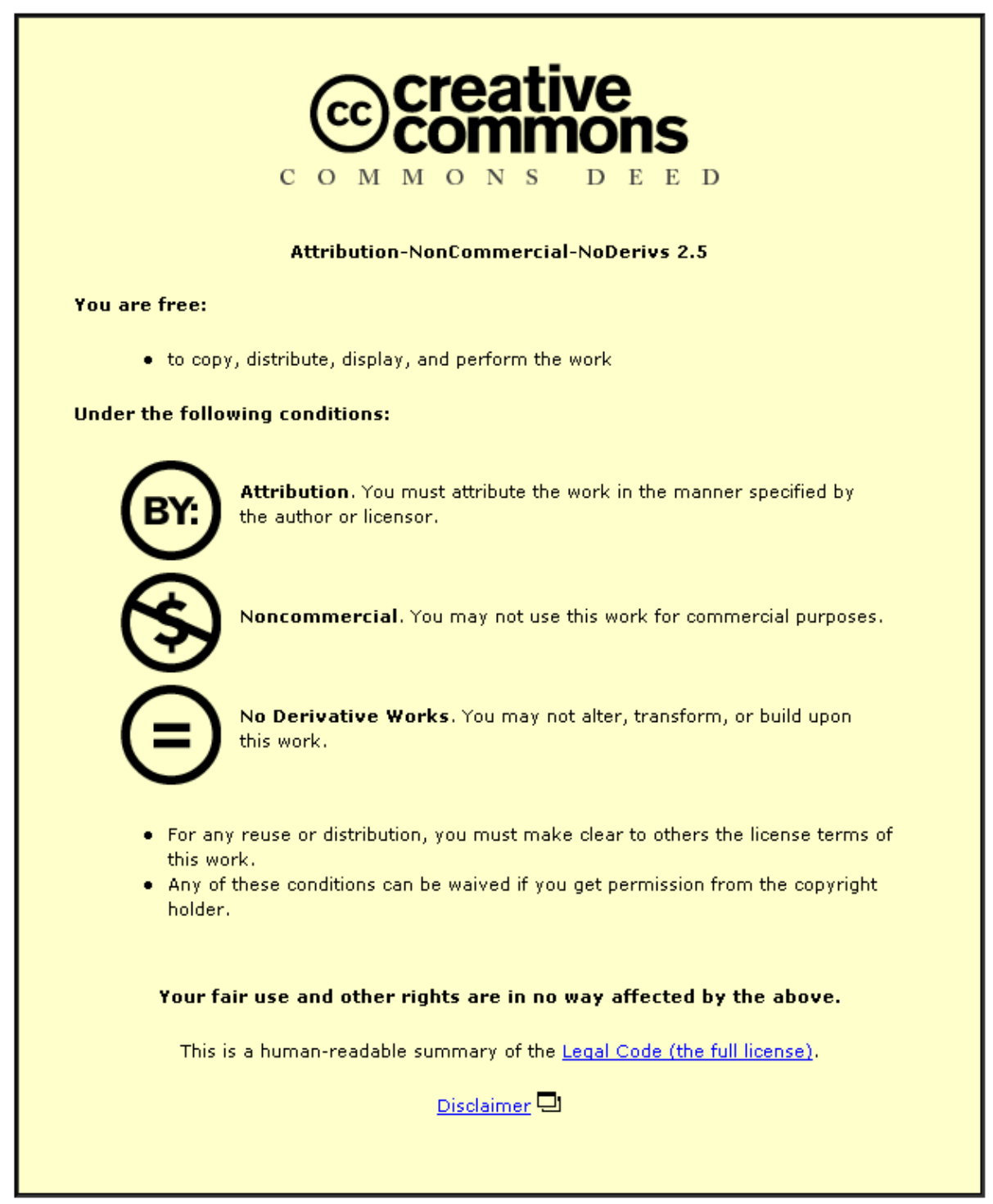

For the full text of this licence, please go to: http://creativecommons.org/licenses/by-nc-nd/2.5/ 


\title{
A Consideration of Reflexive Practice Within the Critical Projects Movement Dan Sage, Andrew Dainty and Naomi Brookes
}

\begin{abstract}
This paper offers a theoretical commentary on some of the new directions in project management theory offered by the critical projects movement. Specifically it examines the implications of a specific approach to knowledge - dialectics - that is implicitly mobilized within this movement. It examines the dialectic provenance of much of this thinking: dialectics is afforded an implicit importance within critical project management as it offers a more reflexive approach to both understand and manage projects. In pursuing this examination, this paper positions the critical projects movement within a broader set of critical studies of reflexive management. We examine how these understandings of reflexivity might inform project management itself and help shed light on some important assumptions that critical project thinkers will need to address whilst using dialectic thinking. The aim is to open up new debates within these modes of thinking, and to encourage further explorations of their implications for understandings of practice amongst those interested in more reflexive approaches to project management practice and research.
\end{abstract}

Keywords: Critical Project Management, Reflexivity, Dialectics, Power 


\section{Introduction}

Critically minded scholars have increasingly questioned the efficacy and socio-political consequences of applying standardized and rationalist knowledge to manage projects (Cicmil and Hodgson, 2006; Clegg and Courpasson, 2004; Hodgson and Cicmil, 2007a, Lindgren and Packendorff, 2006; Smith, 2007). In this paper we consider some alternative approaches to practitioner-based knowledge creation that have thus far been proposed in the wake of this critical movement and the impact of these ideas across the broader project management community. Given the need for relevant practioner knowledge to arise from such critical debates (Morris, 2007) this critical movement is increasingly being translated into a fresh set of approaches to project management knowledge. The continued problems that project-based practioners face in attempting to apprehend the levels of uncertainty and social complexity experienced on many projects make such knowledge all the more pertinent (Cooke-Davies, 2007, Perminova et al, 2008). The critical movement regularly emphasizes reflexivity to overcome various contradictions seemingly present in project-based working, including - codified vs. tacit knowledge production, managerial control vs. worker creativity, or more generally structure vs. agency. Reflexive approaches promise a radically different way to engage with projects overcoming some of the hard vs. soft dichotomies apparent in systems thinking (Kerzner, 2003). However, while this new path of project management thinking appears fresh, it could be considered as focusing on an approach to knowledge creation that is actually traditional both in its intellectual origins and scope for creating new knowledge, namely dialectics. 
This paper is organized around three sections. It begins with a short synopsis of the 'Critical Projects Movement' (CPM). It then examines the reflexive approach prominent within this critical movement. Secondly, it positions these approaches within the dialectical tradition of knowledge creation. Thirdly, it draws upon dialectical critiques within critical management and organizational studies to suggest some important unexamined assumptions that have consequences for the way reflexive management has been conceptualized as central to the production of novel project-based knowledge.

But first, we would like to stress two important caveats to the argument presented here. To begin with we must recognize the inherent problems in categorizing a diverse collection of authors under discrete banners; especially given the intersections between overtly 'critical' project management research and more 'mainstream' authors, as evidenced by the diverse contributions to the EPSRC Rethinking Project Management Network (cf. Maylor, 2006). Indeed one imperative of critical thinking must surely be to confront rather than police the divisions associated with the labels 'critical' / 'mainstream', not least to mitigate the possibility that the CPM, or critical management studies more generally, becomes detached esoteric critique (cf. Cicmil et al. 2009: 86-7). The intention of this paper is to address a common reflexive understanding of knowledge (or epistemology) developed across a divergent group of authors, but which happens to be articulated most evidently by authors self-identified as 'critical' in orientation. The paper looks beyond this group of authors to examine the resonances and implications of this way of thinking for the wider field of project management research. Despite the divergent sources of theoretical and methodological inspiration found across the authors 
discussed, it is still possible to bring to light a number of shared aims, assumptions and outcomes.

Secondly, the intention of this paper is to provide a theoretical critical intervention, in other words, to address extant thinking about practice rather than provide an instant contribution to project management practice. In this sense, this paper operates at a level of abstraction that is closer to the critical projects movement, and critical management thinking more generally, than it is to much mainstream project management research. To execute this task, this paper predominately draws upon the voices of other project thinkers to provide the material for its argument rather than project practitioners. Whilst we acknowledge that the paper could be accused of being overly rhetorical, abstract or negative, we assert the on-going need for a critical, and sometimes even provocative debate around the origins, limitations and practical implications of any theoretical perspective, including 'critical' perspectives.

\section{The Case for Critical Project Management}

Since 2003 a series of workshops, entitled Making Projects Critical, have provided a platform for academics across the social sciences to draw upon divergent theoretical perspectives, in particular Critical Management Studies (CMS) and continental philosophy, to question some of the dominant nostrums of project management research. These workshops parallel a growing critical interest across management and organizational studies (MOS) scholars in the 
assumptions and consequences of project-based work (Clegg and Courpasson, 2004; Lindgren and Packendorff, 2006; Bresnen, 2008; Styhre, 2006; Sahlin-Anderson and Sonderholm, 2002, Hodgson, 2002, 2004, 2005). In 2006 this growing body of work was translated into an edited collection (Hodgson and Cicmil, 2006a) and has more recently been developed within a special issue of the journal Ephemera (Cicmil et al. 2009). The imperative for critical project studies ostensibly revolves around two core concerns. The first aspect largely concerns a socio-political critique of the professed post-bureaucratic nature of project-based work, especially the effects of instrumentalist project management guides (i.e PMBoKs) (Clegg and Courpasson, 2004; Hodgson and Cicmil, 2006b, Hodgson and Cicmil, 2007b). Here particular attention is given to the way rationalist and standardized project management helps foster a society in which "job fragmentation, managerial control and surveillance" (Hodgson and Cicmil, 2006b: 34) become normalized at the expense of practitioner reflexivity (Cicmil et al, 2006), work-life balance (Styhre, 2006), democracy (Clegg and Courpasson, 2004), ethical pluralism (Cicmil and Hodgson, 2006; Crevani and Lennerfors, 2009; Nocker, 2009), gender equalities (Gill, 2002; Lindgren and Packendorff, 2006), and organizational improvement (Bresnen, 2008, SahlinAnderson and Sonderholm, 2002). This concern might also be exampled by the intense stress levels experienced by many project managers which has been shown to impact upon project and company value in variety of contexts (Aitken and Crawford, 2007; Flyvbjerg, 2006; Lindgren and Packendorff, 2007). Hence, providing a way of fostering employee morale and job satisfaction alongside project performance would appear a valuable aim. The second related, though perhaps more normative concern, centers upon the development of new forms of project management practice, training and education that are better able to apprehend social complexity, power relations and tacit knowledges and self-reflexive practice (Cicmil et al, 2006; Cicmil and 
Hodgson, 2006, Hodgson and Cicmil, 2006, 2007). A variety of conceptual approaches have been proposed to articulate such project actualities. This paper is primarily concerned with the second rather than the first concern, though as will be shown there are important connections, and even tensions, between the two.

The practical applicability and relevance of formal project management knowledge has been a concern for project researchers for sometime (e.g. Crawford and Pollack, 2007; Morris et al, 2000; Morris and Jameison, 2005; Morris et al, 2006). Clearly both of these problematics are pertinent to project-based practitioners and researchers. Both featured, to varying degrees, within the diverse output of the EPSRC funded Rethinking Project Management Network (2004-6), and were disseminated within a special issue on Rethinking Project Management in IJPM (Maylor, 2006). Whilst the remit and contribution of the RPM was broader than the abovementioned problematics, they are both compatible with the RPM's mission to question self-evident project management knowledge. Indeed, it is noticeable how many recent publications within project management journals have sought to question some of the underlying assumptions associated with PM knowledge, including, inter alia: the rise of social constructivism as an alternative epistemology to positivism (Bellini and Canonico, 2008; Crawford, 2006; Jackson and Klobas, 2008), the shift from 'etic' to 'emic' knowledge (Leybourne, 2007), 'being' to 'becoming' ontologies (Linehan and Kavanagh, 2006; Segercrantz, 2009), Mode 1 to Mode 2 knowledge (Cicmil and Marshall, 2005) and the increasing number of papers focusing on more tacit dimensions of managerial practice (Morris and Jameison, 2005). 
These approaches can be summarized in terms of a shift towards 'bottom-up' craft-based approaches that emphasize value (however defined), tacit knowledge, (self) reflexivity and social complexity, over the instrumental control of narrow cost/time/quality objectives (cf. Smith, 2007). This shift can itself be located within a broader turn within MOS towards practice (Barry and Hansen, 2008). Such a change demonstrates the CPM's agenda to identify its socio-political critique of mainstream PM knowledge as a necessary antecedent to more effective, relevant and above all reflexive practitioner engagement. An elaboration of this reflexive epistemology is provided by Cicmil, via Aristotle's concept of 'phronesis', or practical prudence or wisdom (see Cicmil et al, 2006, Cicmil, 2006). Phronesis operates in logical opposition to 'episteme'/'techne' (abstract/technical knowledge, or here instrumental rationality) (Cicmil, 2006). Cicmil introduces phronesis, as "a form of action that is fundamentally contingent on context-dependent judgment and situational ethics" (Cicmil, 2006: 30). A journey is identified here from a 'novice' dependent on instrumental rationality, to an 'expert or virtuoso' who is able to cultivate value-rationality through tacit learning and intuitive judgment (Cicmil, 2006). This 'expert' is a unique synthesis of instrumental rationality and value rationality - mainstream instrumentalist knowledge applied reflexively alongside political, emotional and ethical wisdom. This expert figure is capable of, "intuitive, synchronous understanding of the situation with an overarching participative critical reflection of the self and group", whereby "the thought, body, knowledge and action are inseparable, are simultaneously forming and are being formed by one another” (Cicmil, 2006: 35). The key to reaching this state of reflection on the limits of instrumental rationality and the exigency for value rationality is practice: "Project management education should enable the development of concrete, context-dependent knowledge by encouraging reflective participative understanding of organizational processes as circular complex responsive process of 
conversational and power relating” (Cicmil, 2006: 36). This approach seeks to dilute the grandiose claims found in 'best practice' manuals, with more sustained reflection on the social milieu of project management - fostering ways to understand the contingent structural factors and power relations that shape individual behavior, stakeholder interests and their consequences (Cicmil and Marshall, 2005).

These oppositions between instrumental and value rationalities assemble a series of more profound oppositions between mind/body, theory/practice, control/creativity, reason/emotions, structure/agency, all of which appear to be reconciled in the self-reflexive figures of the 'expert' project practitioner and pragmatic researcher (Cicmil, 2006: 35). Such attempts to overcome oppositions between theory and practice have also become prevalent within broader PM research. While this work is not explicitly inspired by the critical theorists favored within CPM, it has developed critiques of formal project management in a remarkably similar fashion. Morris et al. (2006: 719), for example, suggest how the limitations of the PMBoK may be partly due to its neglect of embodied knowledge. Similarly, the RPM concluded how PM is a balance of craft/tacit and codified/formal knowledge (Morris et al, 2006). Reflexivity is often presented as the key strategy to overcome theory-practice gaps within PM (Crawford and Pollack, 2007; Crawford, 2006; Crawford et al, 2006; Winter, 2006). Notable reflexive strategies include critical discussions by practitioners of extant best practice solutions (Crawford et al, 2006), the use of visual tools to align project stakeholders, as in Soft-Systems methodology (Winter, 2006) attempts to describe social encounters through complexity theories (Cooke-Davies et al, 2007) and expanded workplace-based or craft orientated training (Smith, 2007). And importantly, the possibility of reconciling thought (mind/theory/control/reason/structure) and action 
(body/practice/creativity/emotions/agency) (Cicmil et al, 2006) chimes with wider political calls for more 'academic-industrial’ partnerships (Winter et al, 2006).

Across these outwardly divergent authors we can detect a drive to first identify and then overcome inter-related contradictions facing project management including: instrumental (or technical) vs. value rationality (Cicmil, 2006), practitioner vs. researcher (Crawford, 2006), theory vs. practice (Crawford and Pollack, 2007), power vs. ethics (Cicmil and Hodgson, 2006), control vs creativity (Hodgson and Cicmil, 2007b), structure vs. agency (Cicmil et al, 2006), and rational planning vs. practical/tacit wisdom (Maylor et al, 2006, Crawford et al, 2006; Smith, 2007). The consistently proposed solutions to these dichotomies are calls for more theoretically reflective practice/practitioners and its academic counterpart more pragmatically reflective research/researchers (Cicmil, 2006). Although these approaches promise to resolve a plethora of contradictions that appear immediately attractive in the light of compelling socio-political critiques of instrumentalist project management (Hodgson and Cicmil, 2006a), there is currently a lack of a counter critique in relation to their own limitations. In seeking to contribute to the burgeoning debate that this body of critical work has ignited, this paper examines some of the philosophical debates surrounding reflexive approaches to knowledge creation. More specifically we argue for further examination of the dialectical character of these perspectives.

\section{Introducing Dialectics}


The concept of dialectics can be traced to the opening pages of Plato's [427-347 BC] The Republic, where Socrates has a conversation with Cephalus about the nature of justice. Cephalus proposes that justice is about paying your debt and being true. Socrates countered this with the example of a friend who has lent you a weapon and then lost his mind - "surely it would be generally agreed that one ought not to return it, and that it would not be right to do so, nor to consent to tell the strict truth to a madman" (Plato, 2003: 331c). Here there is a thesis and its antithesis placed in contradiction, which provoke a problem that can then be resolved in a synthesis of the two positions, as presented by Polemarchus: "Giving a man his due" (Plato, 2003: 331e) that is, to "help and injure one’s friends and enemies [respectively]" (Plato, 2003: 332d). Socrates then presents another antithesis, logically deducing how stealing to help a friend must therefore be considered 'just' (Plato, 2003: 334b). This search for justice continues across the opening section of The Republic, in the dialectical sequence of thesis-antithesis-synthesisthesis.

While for Plato dialectics was limited to a mode of logical argumentation, for Georg Hegel, the German philosopher [1770-1831], the dialectic could explain all of human society and knowledge and change. Hegel wrote: "Everything around us can be regarded an example of dialectic. For we know that, instead of being fixed and ultimate, everything finite is alterable and perishable...life as such bears the germs of death within itself, and that the finite sublates itself because it contradicts itself inwardly" (Hegel, 1998: 171-2). Hegel's dialectic proposes that knowledge only progresses through a paradoxical unity of contradictions, what he termed the "Sprit” (Hegel, 1977: 5): the transformative movement towards absolute knowledge, truth and reason. Hegelian dialectics has influenced theories of how individual knowledge forms in co- 
relation with society, rendering both terms transformed. Hegel's ideas have influenced Marxist social theory, as well as American pragmatists, such as George Mead, the grounded theorist Anselm Strauss, and the reflexive management theorist Donald Schon.

\section{Dialectics and the CPM}

Although dialectics has featured explicitly in studies of modern organizations (Clegg et al, 2002; Collinson, 2005; Cunha, 2004; Hancock and Tyler, 2001; Ogbor, 2001), its appearance within project management research is rather less explicit. Notably, however, many of the theoretical influences that the CPM has, thus far, drawn upon, such as Anthony Giddens, Pierre Bourdieu, David Harvey, Jurgen Habermas and Donald Schon, have all been influenced by Hegelian dialectics. It is important to reflect upon the important theoretical influence of dialectics in the burgeoning CPM, and its lessons for turns towards reflexivity.

The dialectical provenance of the PM authors discussed so far requires some detailing. Dialectics begins with the assumption of an opposition between two perspectives or interpretations on the world (thesis-antithesis). To example this process, we might cite Cicmil's already mentioned oppositions between instrumental and value rationality, or Morris’s distinction between codified knowledge and craft knowledge. For Hegel, the next movement is a transformative synthesis between these two interpretations, where the original meanings of each are modified, and the distinctions negated (Stacey, 2003: 212). As has been shown within the CPM this unity between 
codified and craft knowledge (or theory and practice) seems to come about through two concepts - the reflective practitioner and pragmatic researcher (Cicmil et al, 2006). Hegel's concept of 'Spirit' can also be read as an overview of this process of accumulating knowledge through (self) reflection: "this is nothing but [the] acquisition of self-consciousness, the bringing-about of its own becoming and reflection into itself” (Hegel, 1977: 17).

This account of Hegel could be seen as reflecting the 'virtuoso' or 'expert' project-practitioner, a figure who appears fully self-reflexive (Cicmil, 2006). A further direct parallel between much of the CPM and Hegel's philosophy is the way knowledge is seen to accumulate through a transformative process of synthesis, whereby contradictory thought of the type 'thesis-antithesis' is resolved, such as the knowledge/action binary can be overcome by exampling how knowledge is found in action and action in knowledge. Of prime importance to any dialectical approach to management is the identification of dualisms, whether this is codified/craft knowledge, structure/agency, self/other, mind/body, theory/practice, power/resistance or control/creativity. The originator of the term 'reflective practitioner', Schon, whose work (see Schon, 1991) has influenced the CPM (Smith, 2007) and RPM (Morris et al, 2006), provides many examples of dialectical reasoning, including an account from a manager who uses the expression dialectics to inform his own practice:

I feel good when I see that engineering and development, advertising and manufacturing, are really surfacing in and talking about their differences. It's my job to keep the dialectic 
alive... Once you have identified the conflicts you see to it that they resolve them and that they let you know the result (quoted in Schon, 1991: 254)

More tellingly, perhaps, Schon (1991) draws upon a dialectical perspective to define his influential model of the reflective practitioner. It is worth quoting one such definition at length to appreciate its dialectical character:

From the perspective of Technical Rationality, professional practice is a process of problem solving [thesis]...But with this emphasis on problem solving, we ignore problem setting, the process by which we define the decision to be made, the ends to be achieved, the means which may be chosen [antithesis]...When someone reflects-in-action, he becomes a researcher in the practice context...He does not keep means and ends separate, but defines them interactively as he frames a problematic situation. Thus reflection-inaction can proceed, even in situation of uncertainty or uniqueness, because it is not bound by the dichotomies of Technical Rationality [synthesis] (Schon, 1991: 39-40).

After acknowledging the dialectical provenance of current moves towards reflexive practice, particular within the CPM, we will now re-position this work alongside recent dialectically informed studies of organizations within critical management and organizational studies. In so doing, we will unpack some important unexamined assumptions surrounding the way reflexive practice, and dialectical thinking, has been hitherto conceptualized within some avenues of 
project management theory. Before doing so, we should note that there exist more profound criticisms of dialectic reasoning, and dualistic thought, found across the social sciences and humanities, particularly by writers usually labeled 'post-structuralist’ (e.g. Butler, 1990; Derrida, 1976; Doel, 1999; Latour, 1993; Law, 1991; Thrift, 2008). It is beyond the scope of this paper to expand upon these external critiques here, though we do not wish to downplay their relevance to critical project studies (see Hodgson and Cicmil, 2006a). Instead, we develop an internal critique that is broadly consistent with Hegelian dialectical reasoning as outlined above.

\section{Dialectical Critique}

While it is perhaps possible to see how the practice of dialectics, with its Enlightenment thirst for totality, order, progress and absolute self-reflective knowledge, might seemingly undermine some of the critical aspirations advocated by the CPM, a number of specific criticisms are perhaps even more important to project practitioners and critically minded project-based researchers. The critique presented here focuses upon the all-encompassing dialectical synthesis - the virtuoso reflective practitioner - a synthesis of instrumental/value rationality, knowledge/action, mind/body, theory/practice and above all perhaps project-based control/creativity. Several critical management studies illustrate how reflective practitioners have been positioned as central to new forms of managerial power, organizational rigidity and cryptobureaucratic working practices, so as to paradoxically inhibit rather than emancipate employee and organizational creativity and flexibility. 
The work of Ogbor (2001) is particular salient to any understanding of (self) reflexivity within modern organizations. Ogbor's assessment of corporate culture illustrates how managerial control is increasingly being reworked through Hegelian efforts to first identify and then resolve a dualism of control/creativity. Ogbor describes how if the alternatives to managerial control are only those proposed by the organization - as in recourse to reflective practice - then "It is as if employees are being empowered through corporate culture to dis-empower themselves” (Ogbor, 2001: 603). For example, reflective training sessions become replete with paradoxes of control whereby "employees are indoctrinated to carry out that which is sanctioned by management" such that "employees are provided with the skills that enable them to regulate themselves in the absence of managerial gaze” (Ogbor, 2001: 602). Here value rationalities, such as creativity and autonomy, are channeled into new reflexive practices of internalized control and self-discipline, "where employees turn the disciplinary gaze upon themselves through the assimilation of cultural values and norms" (Ogbor, 2001: 603). (Self) reflection per se cannot mitigate bureaucratic regimes and enabling worker creativity. The fashion for autonomy and creativity, and other value rationalities, as a reflexive counterpoint to instrumentalist control is rendered equally problematic in the work of Cederstrom and Grassman (2008). In their analysis of Google they describe how the culture of 'being yourself' and being free to reflexively express yourself and your own ethics, as opposed to following bureaucratic orders, can "create new forms of identity control” (p45), whereby employees own idiosyncratic identity is conflated with corporate identity, creating a 'false consciousness' with which to extract longer working hours and commitment, increasing the colonization of work into personal lives. 
Even Hegel himself recognized the potential for the reflectively self-conscious individual to become subsumed in extant power relations when he wrote:

Self-consciousness exists in and for itself when, and by the fact that, it so exists for another; that is, it exists only in being acknowledged (Hegel, 1977: 111).

In other words we can only become ourselves through our relations with others - their recognition of our self-reflexivity and vice-versa (cf. Ogbor, 2001). If the template for reflexivity is the experienced 'virtuoso' practitioner (Cicmil, 2006), or follower of a ProjectCraft workshop (Smith, 2007), then this only legitimizes hierarchical patterns of managerial control by valuing a mode of autonomy and reflection sanctioned by senior project-based practitioners. If reflection, and its conceptualization, becomes the elusive and rarefied property of managerial discourse, popularized by its capacity to seemingly resolve contradictions of control/creativity, then perhaps it can only lock many practitioners more tightly into regimes of managerial control (Ogbor, 2001, Cederstorm and Grassman, 2008). Collinson (2005) describes the example of masculine working cultures in modern organizations which promote a sense of independence and selfreliance that locks workers' self-identity into their exploitation by the company and diminishes their power to resist as a collective.

Clegg et al. (2002) elaborate such paradoxes through the concept of false synthesis. In developing this concept, Clegg et al. (2002) cite Baker’s (1993) study of a high-technology 
company that shifted from hierarchical rule-based management to value-based self-managed teams. This organization, as Baker (1993) described, framed this shift as a means to cut the costs of bureaucracy, providing greater productivity and creativity to adapt in a dynamic marketplace. However, as Baker (1993) notes, self-managed teams paradoxically seem to enhance forms of control within organizations - employees invest their own dignity and self-identity into reflexively policing cultural norms in a manner much more effective than rule-based formal supervision. Moreover, the self-managed teams, in Baker's (1993) study, eventually decided to instigate hierarchical forms of surveillance, by electing team co-ordinators, whose role was remarkably similar to the preceding line managers. Baker's (1993) study offers a powerful caution to those who would like to believe that there is a clear distinction to be made between value and instrumental rationalities, and that reflexivity per se provides a symmetric arbitrator between the two poles. Indeed, it is hard to imagine how creativity and flexible working practices might prosper in an environment in which peer-pressure and guilt impose rigid cultural norms (Baker, 1993), such as long working hours or strict lines of responsibility, while simultaneously rendering such control almost invisible as it works with the dignity and selfidentity of employees. Clegg et al. (2002) summarize the dialectical contours of Baker's (1993) study through the notion of 'false synthesis':

By choosing 'autonomy' or by striking a balance closer to this pole of 'control', the organization achieved an apparent synthesis between two opposing strategies. However, it was a false synthesis inasmuch as autonomy as a strategy resulted in a pervasive and unobtrusive control mechanism, albeit one presented under the guise of a participatory and 'liberating' practice. (Clegg et al, 2002: 488; emphasis added). 
In all these examples the promise of greater 'autonomy' or 'self-reflexivity' to overcome the paradox of control/creativity or instrumental/value rationality, ends up strengthening managerial power and organizational inflexibility, providing a false synthesis that settles much closer towards the 'control' pole of the binary. This paradox seemingly inhibits its attractiveness as a radically different solution to mainstream instrumentalist thinking to develop PM knowledge and practice. We might push this point further and argue, with Fleming and Spicer (2003), that strict rule-following may itself provide a better means to short-circuit managerial control, ultimately providing greater opportunities to foster creativity and autonomy. Indeed, the phrase, 'working to rule', has indeed often been viewed more as a means of dissent than obedience. If we follow Cicmil et al.'s (2009) warnings of the crises in the rationalist façade of structured PM knowledge, then we might add that perhaps more un-reflective rule following not less may quicken the transformation of such logics.

The cited studies demonstrate how many of the oppositions and outcomes of the dialectical thinking of the CPM, in this case its turn to reflexivity as a synthesis or reconciliation of control/creativity; have arguably already been reworked into new forms of managerial control within various organizational settings. This stream of work illustrates how seductive thesisantithesis oppositions, inherent within dialectics, may sometimes be resolved in a false synthesis that to all practical purposes ends up settling back on one of the terms of the dualism, in this case providing new justifications and conduits for managerial control and organizational stasis. 
There are parallels between this critique of reflexivity as an antidote to managerial control and the socio-political critiques that some critical project thinkers have leveled at 'mainstream' project management thinking. Critical project thinkers have questioned the view that project organizations are inherently post-bureaucratic (cf. Clegg and Courpasson, 2004; Crevani and Lennerfors, 2009; Hodgson, 2004). In so doing, they have proposed that the labeling of projectbased organizations as post-bureaucratic - evidenced by their apparently flexible, temporal and collaborative nature - provides managers with a rhetoric of 'empowerment', 'equality', 'trust', ‘creativity', ' 'teamwork’ and 'autonomy’ that simultaneously enables and masks their complicity with relativity bureaucratic practices of control, prediction, distrust, stress and competition, including performance monitoring and a host of industry standard PMBoK's based on the 'iron triangle' of cost, time and quality.

One of the problems with applying, either explicitly or implicitly, Hegelian dialectics to empirical examples is that it seems to imply that any synthesis represents an advance of human knowledge to the universal benefit of all, rather than a differentiated reworking of knowledge/power whose effect must be understood through empirical cases, such as those cited above. These critical studies illustrate how the dialectic synthesis is always at risk of omitting a remainder: for example, the cases above suggest examples of forms of power that creatively work through highly reflexive individuals rather than assume organizations are populated by passive management pawns. The problem of a remainder (or further paradox) to a seemingly fully coherent concept is, of course vital to Hegelian dialectics. 


\section{Concluding Comments}

Discourses of reflexive, or reflective, management offer a seductive means of forging synergy between 'mainstream' and 'critical' approaches in a project context. In using these conceptualizations, however, critical project management theoreticians need to be wary that the thirst for relevance (Cicmil et al. 2009: 86-87), which frames moves to reflexivity, does not hide from view complex realities, and novel power relations, found within project-based organizations. Specifically, if a reflexive approach is adopted, questions of empirical complexity, paradox and multiplicity may be resolved within obscure dialectical movements between cumbersome oppositions (such as control/creativity, power/resistance, instrumental/value, structure/agency, theory/practice and mind/body etc). While, we agree with Nocker (2009) that the standardization of project management knowledge elides a great deal of the complexities found in the lived experience of project work, we would like to urge caution to those attracted by the various dialectical discourses of reflexive practice as a novel reframing of such social complexities.

Dialectics, especially when not consistent with the open-ended and transformative movement of Hegel's philosophy, can become an unreflective way of generating new concepts; driving forward closed syntheses of unexamined binary oppositions. Employed in this way, this outwardly transformative mode of thinking (thesis-antithesis-synthesis) could inhibit the potential to produce radically new concepts. If project management thinkers are to answer earlier calls (Hodgson and Cicmil, 2006a; Hodgson and Cicmil, 2007a) to develop new theories in 
tandem with current critical debates across the social sciences and humanities, it is crucial that they are as cogniscient of the implications, and conceptual heritage of their choice of conceptual starting points as they are of the need to question instrumentalist and positivist perspectives. This point notwithstanding, it is also important to stress that the aim of this paper is not to seek to close down the CPM, or indeed dialectical reasoning, as a route to different understandings of project actualities. Indeed, such approaches have been extremely valuable in exposing some of the limitations of much mainstream PM thinking, particularly their elision of socio-political contexts. Rather, the aim is to open up greater critical awareness, and new debates, within these modes of thinking, and their implications for understandings of practice. Moreover, if we are to adhere to the reflexive modus operandi of Hegelian dialectics, then the need for divergence (antithesis) is as important as consensus (thesis/synthesis). In this paper we have sought to provide a supplementary perspective, via a critical examination of reflexive practice, and the possibility of false-synthesis, to open up fruitful avenues for research that are conceptually orthogonal to the dialectic approaches emerging in new ways of thinking about projects.

\section{Acknowledgements}

We would like to thank the three anonymous referees for their useful comments on an earlier draft of this paper which have helped to shape and sharpen the arguments contained within it.

\section{References}


Aitken A, Crawford. L., 2007. Coping with stress: dispositional coping strategies of project managers. Int J Project Manage, 25, 666-673.

Barker J R. (1993) Tightening the Iron Cage: Concertive Control in Self-Managing Teams, Admin Science Quarterly, 38, 408-437.

Barry D, and Hansen H., 2008. The Sage handbook of new approaches in management and organization. Sage, London.

Bellini E, Canonico P., 2008. Knowing communities in project driven organizations: Analyzing the strategic impact of socially constructed HRM practices. Int J Project Manage. 26, 44-50.

Bresnen, M., 2008. Deconstructing partnering in project-based organization: Seven pillars, seven paradoxes and seven deadly sins, Int J Project Manage. 23, 63-374.

Butler J., 1990. Gender trouble: feminism and the subversion of identity. Routledge, New York.

Cederstrom C. and Grassman R., 2008. The masochistic reflexive turn, Ephemera. 8 (1), 41-57.

Cicmil S., 2006. Understanding project management practice through interpretative and critical research perspectives. Project Manage J. 37(2), 27-37.

Cicmil S, Williams T, Thomas J, Hodgson D., 2006. Rethinking project management researching the actuality of projects. Int J Project Manage. 24, 675-685.

Cicmil, S. Hodgson, D. Lindgren, M. and Packendorff, J. 2009 Project management behind the façade. Ephemera. 9 (2), 78-92. 
Cicmil S, and Hodgson D., 2006. New possibilities for project management theory: a critical engagement. Project Manage J. 37(3), 111-122.

Cicmil S, and Marshal D., 2005. Insights into collaboration at the project level: complexity, social interaction and procurement mechanisms. Build Res and Inform, 33(6), 523-535.

Clegg S, and Coupasson, D., 2004. Political hybrids: tocquevillean views on project organizations, J Manage Stud. 41, 525-547.

Clegg, S, R, da Cunha J V, Cunha M P., 2002. Management paradoxes: a relational view, Human Relations. 55(5), 483-503.

Collinson D., 2005. Dialectics of leadership, Human Relations. 58(11), 1419-1442.

Cooke-Davies T, Cicmil S, Crawford L, Richardson I., 2007. We're not in Kansas anymore, Toto: mapping the strange landscape of complexity management. Project Manage J. 38(2), 5061.

Crawford L, Morris P W G, Thomas J, and Winter M., 2006. Practioner development: from trained technicians to reflective practioners, Int J of Project Manage. 24, 722-733.

Crawford L, and Pollack J., 2007. How generic are project management knowledge and practice, Project Manage J, 38(1), 87-96.

Crevani, L. and Lennerfors, T, S. (2009) Pull yourselves together guys!. Ephemera. 9(2), 113130.

Cunha M. P., 2004. Organizational time: a dialectical view. Org. 11(2), 271-296. 
Derrida J., 1976. Of Grammatology. Translated by G.C.Spivak. John Hopkins Press, Baltimore, MD.

Doel M., 1999. Poststructuralist geographies: the diabolical art of spatial science. Edinburgh University Press Edinburgh.

Fleming, P. and Spicer, A., 2003. Working at a Cynical Distance: Implications for Power, Subjectivity and Resistance, Organization 10(1), 157-179.

Flyvbjerg B., 2006. From Nobel prize to project management: getting risks right. Project Manage J.37(3), 5-15.

Gill, R., 2002. Cool, Creative and Egalitarian? Exploring gender in project-based new media work in Europe, Info, Communications and Society. 5(1), 70-89.

Hancock P, and Tyler M., 2001. Managing subjectivity and the dialectic of self-consciousness: Hegel and organizational theory, Org. 8(4), 565-585.

Hegel, G. W. F., 1977. Phenomenology of spirit. Translated by W.Wallace and A.V.Miller. Clarendon, Oxford.

Hegel, G. W. F., 1998. Encyclopedia logic. In: Houlgate S. (Ed.), The Hegel reader. Blackwell, Oxford.

Hodgson D., 2002. Disciplining the professional: The case of project Management. J Manage Stud. 39(6), 803-821. 
Hodgson D., 2004. Project Work: The legacy of bureaucratic control in the post-bureaucratic Organization, Organization, 11(1), 81-100.

Hodgson D., 2005. Putting on a professional performance': performativity, subversion and project management. Organization, 12(1), 51-68.

Hodgson D, and Cicmil S. (Eds.), 2006a Making Projects Critical. Palgrave, Hamsphire, UK.

Hodgson D, and Cicmil, S. 2006b. Are projects real? The PMBOK and the legitmation of project management knowledge. in: Hodgson D, and Cicmil S. (Eds.), Making Projects Critical. Palgrave, Hampshire, UK. pp. 29-50.

Hodgson D, and Cicmil, S., 2007a. The other side of projects: the case for critical project studies. Int J Manage Project Business. 1: 142-152.

Hodgson D, and Cicmil S., 2007b The politics of standards in modern management: making 'the project a reality’ J Manage Stud. 44, 431-450.

Jackson P, and Klobas J., 2008. Building knowledge in projects: a practical application of social constructivism to information systems development Int J Project Manage. 26, 329-337.

Kerzner H., 2003. Project management: a systems approach to planning, scheduling and controlling. Hoboken, John Wiley and Sons: New Jersey.

Latour B., 1993. We have never been modern. Translated by C Porter. Harvester Wheatsheaf, London.

Law J., 1991. Power, discretion and strategy. in: Law J. (Ed.), A sociology of monsters: essays on power, technology and domination. Routledge, London, pp.165-191. 
Leybourne S A., 2007. The changing bias of project management research: a consideration of the literature and an application of extant theory. Project Manage J. 38(1), 61-73.

Lindgren, M and Packendorff, J., 2006. What's new in new forms of organizing? On the construction of gender in project-based work, J Manage Stud. 43, 841-866.

Lindgren, M and Packendorff, J., 2007 Performing arts and the art of performance - On coconstruction of project work and professional identities in theatres, Int J Proj Manage. 25, 354364.

Linehan C, and Kavanagh D., 2006. From project ontologies to communities of virtue. In: Hodgson D, and Cicmil S. (Eds.), Making Projects Critical. Palgrave, Hampshire, UK, pp. 51-67.

Maylor, H., 2006 Special Issue on Rethinking Project Management (EPSCR Network 20042006), Int J Proj Manage. 24 (8), 636-637.

Maylor H, Brady T, Cooke-Davies T, and Hodgson D., 2006. From projectification to programmification. Int J Project Manage. 24, 663-674.

Morris, P.W.G., 2006 Afterword: making the management of projects critical. in: Hodgson D, and Cicmil S. (Eds.), Making Projects Critical. Basingstoke, Hampshire, UK: Palgrave: Hampshire, UK; pp. 335-347.

Morris P W G, Patel M B, and Wearne S H., 2000. Research into revising the APM project management body of knowledge., Int J Project Manage, 18, 155-64.

Morris P W G, and Jameison A., 2005. Moving from corporate strategy to project strategy, Project Manage J, 36(4), 5-18. 
Morris P W G, Crawford L, Hodgson D, Shepherd M M, Thomas J., 2006. Exploring the role of formal bodies of knowledge in defining a profession - the case of project management. Int $\mathrm{J}$ Project Manage. 24, 710-721.

Perminova O, Gustafsson M, Wilkstrom K., 2008. Defining uncertainty in projects a new perspective. Int J Project Manage. 26,73-79.

Plato., 2003. The Republic. Translated by D.Lee. Penguin, London.

Sahlin-Anderson, K. and Soderholm, A. (Eds), 2002. Beyond project management: new perspectives on the temporary-permanent dilemma, Liber Press, Copenhagen.

Schon D., 1991. The Reflective Practitioner: How Professionals Think in Action, Ashgate, Aldershot.

Smith C., 2007. Making Sense of Project Realities. Gower, Aldershot, UK.

Stacey, R, D. 2003. Complexity and group process: a radically social understanding of individuals. Brunner-Routledge, Hove.

Styhre, A., 2006. The bureaucratization of the project manager function: The case of the construction industry, Int J Project Manage. 24, 271-276.

Thrift, N., 2008. Non-Representational Theory: Space, Politics, Affect. Routledge, London.

Winter M., 2006. Problem structuring in project management: an application of soft systems methodology (SSM). J of Operate Res Soc, 57, 802-812. 
Winter M, Smith C, Cooke-Davies T, and Cicmil S., 2006. The importance of 'process' in Rethinking Project Management: The story of a UK government-funded research network. Int J Project Manage. 24, 650-662. 